\title{
Efek Pemberian Magnesium Sulfat Intravena Perioperatif terhadap Nilai Visual Analog Scale (VAS) dan Kebutuhan Analgetik Pascabedah pada Pasien yang Menjalani Pembedahan Abdominal Ginekologi dengan Anestesi Umum
}

\author{
Dhany Budipratama, U. Kaswiyan, Ike Sri Redjeki \\ Departemen Anestesiologi dan Terapi Intensif \\ Fakultas Kedokteran Universitas Padjadjaran Bandung
}

\begin{abstract}
Abstrak
Magnesium sulfat sebagai antagonis reseptor $N$-methyl-D-aspartate (NMDA) dan penghambat saluran kalsium, memiliki efek antinosiseptif dan antihiperalgesia. Penelitian dilakukan secara acak, terkontrol, buta ganda bertujuan untuk menilai efek pemberian bolus magnesium sulfat intravena terhadap nilai visual analog scale (VAS) dan jumlah kebutuhan analgetik petidin pada 30 pasien wanita dengan status fisik ASA I-II, usia 18-60 tahun, yang akan menjalani operasi abdominal ginekologi elektif dengan anestesi umum di ruang operasi bedah sentral Rumah Sakit Dr. Hasan Sadikin Bandung pada Juni-September 2011. Subjek penelitian dibagi menjadi dua kelompok yang akan mendapat bolus dan rumatan $\mathrm{MgSO}_{4}$ intravena (grup M) atau $\mathrm{NaCl}$ 0,9\% (grup S). Hasil penelitian menunjukkan nilai VAS dan jumlah pemberian analgetik petidin pada grup M secara statistik lebih rendah dibandingkan dengan grup $S(p<0,05)$. Simpulan penelitian adalah pemberian bolus magnesium sulfat intravena perioperatif mampu menunjukkan nilai VAS saat mobilisasi pascabedah yang lebih rendah serta mengurangi kebutuhan analgetik pertolongan petidin pada pasien pascabedah abdominal ginekologi dalam anestesi umum.
\end{abstract}

Kata kunci: Analgetik pascabedah, magnesium sulfat, nilai VAS saat mobilisasi, operasi abdominal ginekologi

\section{The Effect of Perioperative Magnesium Sulphate Infusion on VAS (Visual Analog Scale) Scores and Postoperative Analgesic Requirements in Patients Undergoing Gynaecological Abdominal Surgery with General Anaesthesia}

\begin{abstract}
Magnesium sulphate is N-methyl-D-aspartate (NMDA) receptor antagonist and calcium channel blocker with antinociceptive and antihyperalgesia effects. A randomized, double blind, controlled study was conducted to evaluate the effect of perioperative magnesium sulphate infusion on visual analog scale (VAS) scores and cumulative rescue analgesic petidin consumption in 30 ASA physical status I-II female patients, aged 1860 years, scheduled for gynaecological surgery under general anaesthesia in central operating theatre Dr. Hasan Sadikin Hospital-Bandung within June-September 2011. Subjects were divided into two groups that received either intravenous bolus and maintenance of $\mathrm{MgSO}_{4}$ ( $\mathrm{M}$ group) or $0.9 \%$ normal saline (S group). The results showed that postoperative VAS score during movement and the number of analgesic pethidin were significantly lower in $M$ group compared to $S$ group $(\mathrm{p}<0.05)$. In conclusions, intravenous bolus of magnesium sulphate perioperative are able to demonstrate the lower value of VAS during mobilization and reducing the amount of analgesic rescue petidin postoperative abdominal gynaecological surgery.
\end{abstract}

Key words: Abdominal gynaecological surgery, magnesium sulphate, VAS scores during movement

Korespondensi: Dhany Budipratama, dr., SpAn, Departemen Anestesiologi dan Terapi Intensif, Fakultas Kedokteran Universitas Padjadjaran, Jl. Pasteur No. 38, Bandung, mobile 08122467057, email dr_biuzz@yahoo.co.id 
Efek Pemberian Magnesium Sulfat Intravena Perioperatif terhadap Nilai Visual Analog Scale (VAS) dan

\section{Pendahuluan}

The Royal College of Surgeons, pada tahun 1990 melaporkan bahwa sebanyak 30-70\% pasien mengeluhkan nyeri pascaoperasi dengan skala sedang sampai berat. Data penelitian terbaru memperlihatkan $30 \%$ pasien mengeluh nyeri pascaoperasi dengan skala sedang serta $11 \%$ lainnya dengan skala berat. ${ }^{1}$

Nyeri pascabedah mempunyai karakteristik berupa proses sensitisasi di perifer dan sentral susunan saraf yang dikenal juga sebagai nyeri klinis. Ketika terjadi proses sensitisasi sistem saraf, maka stimulus lemah yang normalnya tidak menimbulkan sensasi nyeri akan terasa nyeri (alodinia), sedangkan stimulus kuat yang cukup akan terasa amat nyeri (hiperalgesia). ${ }^{1-3}$

Proses sensitisasi pada masa pascaoperasi akan mengakibatkan penderitaan bagi pasien sehingga akhirnya akan meningkatkan angka morbiditas dan mortalitas pascaoperasi. Oleh karenanya penatalaksanaan nyeri pascabedah harus dititikberatkan pada pencegahan dan meminimalkan terjadi proses sensitisasi. ${ }^{4}$

Tujuanutamapenanganan nyeripascabedah adalah memulihan fungsi organ secara cepat dan juga menghindari komplikasi. Penanganan nyeri yang baik akan mengurangi morbiditas atau komplikasi pascabedah, meningkatkan kenyamanan dan kepuasan pasien, mobilisasi lebih dini, mempercepat penyembuhan, serta mengurangi biaya perawatan rumah sakit. ${ }^{5-8}$

Keberhasilan manajemen nyeri pascabedah berawal dari penilaian kondisi pasien yang bersifat individual, karena nyeri pascaoperasi merupakan pengalaman yang bersifat sangat subjektif sehingga pada setiap individu akan memiliki respons nyeri yang berbeda. Keadaan ini dipengaruhi oleh kebudayaan, pengalaman nyeri, rasa takut, kecemasan, dan juga suasana hati pasien. Berdasarkan hal tersebut, maka keterlibatan pasien sangat diperlukan dalam penanganan nyeri pascaoperasi agar pasien dapat menyampaikan secara langsung rasa nyeri yang dirasakannya. ${ }^{8}$

Pemberian terapi nyeri multimodal dapat mempercepat masa pemulihan, meningkatkan kepuasan pasien, dan dapat mengurangi lama perawatan di rumah sakit. Pasien pascaoperasi abdominal dan torakotomi yang mendapatkan terapi nyeri multimodal terbukti mengalami stres metabolik dan hormonal yang lebih kecil, waktu ekstubasi lebih singkat, skor nyeri lebih rendah, dan waktu pemulihan lebih cepat. ${ }^{9,10}$

Terapi nyeri multimodal dilakukan dengan memberikan opioid sebagai analgetik utama ditambahkan dengan obat analgetik lain (misal parasetamol, inhibitor siklooksigenase, atau antiinflamasi nonsteroid) serta golongan obat koanalgesia (klonidin dan antagonis reseptor $\mathrm{N}$-methyl-D-aspartate (NMDA)), misal ketamin atau $\mathrm{MgSO}_{4}$ (magnesium sulfat)). Penggunaan terapi kombinasi tersebut dapat memperkuat potensi analgetikgolongan opioid, mengurangi kebutuhan dosis, toleransi serta efek samping opioid, dan mempercepat pemulihan pasien. ${ }^{11}$

Magnesium sulfat atau $\mathrm{MgSO}_{4}$ merupakan antagonis dari reseptor $N$-methyl-D-aspartate (NMDA) dan penghambat saluran kalsium ( $\mathrm{Ca}$ channel blocker). Sebagai antagonis reseptor NMDA, magnesium sulfat bekerja menghambat sensitisasi saraf pusat akibat stimulasi perifer serta menghilangkan reaksi hipersensitivitas, magnesium sulfat telah terbukti memiliki efek antinosiseptif melalui penghambatan saluran kalsium. $^{12,13}$

Anestesi serta pembedahan menyebabkan penurunan kadar magnesium di dalam darah (hipomagnesemia) yang akan kembali normal 1 hingga 3 hari pascaoperasi. Hipomagnesemia akan meningkatkan morbiditas dan mortalitas perioperatif, dan nyeri pascabedah, oleh karena itu pemberian magnesium sulfat disarankan pada pembedahan dengan skala nyeri tinggi serta memerlukan pemberian cairan intravena dalam jumlah yang banyak. ${ }^{12,14}$

Dosis magnesium sulfat yang disarankan sebagai adjuvan analgetik pascaoperasi adalah $30-50 \mathrm{mg} / \mathrm{kgBB}$ bolus intravena serta apabila diperlukan dilanjutkan dengan dosis rumatan $7-15 \mathrm{mg} / \mathrm{kgBB} / \mathrm{jam} . .^{15,16}$

\section{Subjek dan Metode}

Penelitian ini adalah penelitian eksperimental dengan melakukan uji klinis rancangan acak terkontrol buta ganda (double blind randomize controlled trial) terhadap 30 subjek di Rumah 
Sakit Dr. Hasan Sadikin (RSHS) Bandung pada Juni sampai September 2011 dengan kriteria inklusi, adalah jenis kelamin wanita, usia 1860 tahun, status fisik ASA I-II yang menjalani tindakan operasi abdominal ginekologi elektif menggunakan teknik anestesi umum. Kriteria eksklusi adalah ketidakseimbangan elektrolit praoperasi, obesitas dengan $\mathrm{BMI}>30$, hamil, dalam pengobatan obat penghambat saluran kalsium, riwayat alergi terhadap obat-obatan yang dipakai dalam penelitian ini serta pasien dengan gangguan neurologis, miopati. Subjek penelitian dibagi menjadi 2 (dua) kelompok, yaitu kelompok magnesium sulfat (kelompok M) mendapatkan magnesium sulfat intravena $30 \mathrm{mg} / \mathrm{kgBB}$ dan dilanjutkan dosis rumatan 10 $\mathrm{mg} / \mathrm{kgBB} / \mathrm{jam}$ sampai akhir operasi dan juga kelompok $\mathrm{NaCl}$ 0,9\% (kelompok S) mendapat bolus $\mathrm{NaCl}$ 0,9\% 0,3 mL/kgBB dan dilanjutkan dengan dosis rumatan sebanyak $0,1 \mathrm{~mL} / \mathrm{kgBB} /$ jam sampai akhir operasi dengan randomisasi secara blok permutasi.

Sebelum operasi semua subjek penelitian dipasang kateter intravena ukuran 18G, lalu dilakukan pemeriksaan terhadap magnesium serum praoperasi yang dilanjutkan pemberian cairan kristaloid $10 \mathrm{~mL} / \mathrm{kgBB}$ sebagai cairan pengganti puasa. Pada saat 15 menit sebelum operasi dimulai, pada kelompok M diberikan bolus magnesium sulfat intravena dosis $30 \mathrm{mg} /$ kgBB selama 15 menit menggunakan syringe pump dan dilanjutkan dengan rumatan $10 \mathrm{mg} /$ kgBB/jam sampai akhir operasi. Kelompok S diberikan $\mathrm{NaCl}$ 0,9\% dengan jumlah 0,3 mL/ kgBB selama 15 menit dengan menggunakan syringe pump serta dilanjutkan dengan dosis rumatan $0,1 \mathrm{~mL} / \mathrm{kgBB} / \mathrm{jam}$.

Ketika di ruang operasi, pasien diposisikan terlentang kemudian dilakukan pemasangan alat pemantau. Induksi anestesi menggunakan propofol $2 \mathrm{mg} / \mathrm{kgBB}$, fentanil $2 \mu \mathrm{g} / \mathrm{kgBB}$, serta atrakurium $0,5 \mathrm{mg} / \mathrm{kgBB}$, tiga menit kemudian dilakukan laringoskopi-intubasi. Pemeliharaan anestesi an menggunakan volatil enfluran dan $\mathrm{N}_{2} \mathrm{O}: \mathrm{O}_{2} 50 \%$. Saat tiga puluh menit menjelang operasi berakhir, diberikan bolus analgetik ketorolak 0,5 mg/kgBB intravena. Selanjutnya analgetik pascabedah menggunakan ketorolak $0,5 \mathrm{mg} / \mathrm{kgBB}$ dan tramadol $2 \mathrm{mg} / \mathrm{kgBB}$ yang diberikan kontinu secara intravena selama 8 jam. Dosis analgetik pascabedah yang sama diberikan sampai 24 jam pascabedah.

Larutan rumatan penelitian ini dihentikan saat operasi akan segera berakhir, kemudian dilakukan lagi pemeriksaan kadar magnesium pascaoperasi. Pasien segera dipindahkan ke ruang pemulihan setelah dilakukan ekstubasi. Penilaian nyeri pascabedah dilakukan dengan menggunakan nilai visual analog scale (VAS) pada saat 30 menit, 1, 2, 3, 4, 6, 12, 18, dan 24 jam pascabedah. Bila nilai VAS lebih dari 3 , diberikan analgetik penyelamatan dengan petidin dosis $0,5 \mathrm{mg} / \mathrm{kgBB}$ dan dapat diulang sampai pasien merasa nyaman.

Perbedaan proporsi nilai VAS pascabedah pada kedua kelompok dihitung menggunakan uji chi-kuadrat. Untuk perbedaan proporsi jumlah analgetik pertolongan petidin yang dibutuhkan selama 24 jam, digunakan Uji Mann-Whitney dengan taraf kepercayaan 95\%, kemaknaan ditentukan berdasarkan nilai $\mathrm{p}<0,05$. Data dianalisis menggunakan program statistical product and service solution (SPSS) 18.0 for Windows.

\section{Hasil}

Perbandingan data karakteristik umum antara subjek penelitian menurut faktor usia, indeks masa tubuh (body mass index/BMI), tingkat pendidikan, prosedur operasi, durasi operasi, pada ke-2 kelompok penelitian secara statistik tidak berbeda, sehingga menunjukkan bahwa karakteristik umum kedua kelompok adalah homogen (Tabel 1).

Kualitas nyeri dinilai dengan menggunakan VAS pada saat mobilisasi. Berdasarkan uji chikuadrat mempergunakan derajat kepercayaan 95\%, nilai VAS pascaoperasi saat mobilisasi pada kelompok $M$ memiliki nilai lebih rendah dengan perbedaan bermakna $(\mathrm{p}<0,05)$ bila dibandingkan kelompok S (NaCL 0,9\%) sampai pengukuran jam ke-6. Nilai VAS pascaoperasi dari jam ke-12-ke-24 tidak berbeda bermakna antara kelompok $M$ dan S. Seperti terlihat pada Tabel 2, rentang nilai VAS saat mobilisasi selama 24 jam pascaoperasi sama pada kedua kelompok perlakuan, yaitu 0-5. 
Tabel 1 Perbandingan Karakteristik Umum Subjek Penelitian antara Kedua Kelompok Perlakuan

\begin{tabular}{|c|c|c|c|c|c|c|c|}
\hline & \multicolumn{3}{|c|}{$\underset{(\mathrm{n}=15)}{\text { Kelompok Magnesium Sulfat (M) }}$} & \multicolumn{3}{|c|}{$\underset{(n=15)}{\text { Kelompok NaCL (S ) }}$} & \multirow{2}{*}{$\underset{\text { p }}{\text { Nilai }}$} \\
\hline & $\mathbf{n}$ & $\begin{array}{l}\text { Rata-rata } \\
\text { (SD) }\end{array}$ & $\begin{array}{l}\text { Median } \\
\text { (Rentang) }\end{array}$ & $\mathbf{n}$ & $\begin{array}{l}\text { Rata-rata } \\
\text { (SD) }\end{array}$ & $\begin{array}{l}\text { Median } \\
\text { (Rentang) }\end{array}$ & \\
\hline \multirow[t]{2}{*}{ Usia (tahun) } & & 37,9333 & 40 & & 39,8667 & 42 & 0,606 \\
\hline & & $(10,892)$ & $(18-54)$ & & $(9,372)$ & $(18-52)$ & \\
\hline BMI $\left(\mathrm{kg} / \mathrm{m}^{2}\right)$ & & 22,442 & 22,64 & & 21,802 & 21,50 & 0,134 \\
\hline Pendidikan & & $(2,102)$ & $(18,83-25,39)$ & & $(1,443)$ & $(18,83-24,22)$ & \\
\hline SD & 4 & & & 6 & & & 0,200 \\
\hline SMP & 8 & & & 3 & & & \\
\hline SMA & 3 & & & 6 & & & \\
\hline Jenis operasi & & & & & & & 0,670 \\
\hline Histerektomi & 4 & & & 6 & & & \\
\hline $\begin{array}{l}\text { Salfhingo- } \\
\text { ovorektomi }\end{array}$ & 6 & & & 6 & & & \\
\hline Kistektomi & 5 & & & 3 & & & \\
\hline Lama operasi (menit) & & $\begin{array}{c}116,2 \\
(27,01)\end{array}$ & $\begin{array}{c}106 \\
(90-168)\end{array}$ & & $\begin{array}{c}123,2 \\
(30,43)\end{array}$ & $\begin{array}{c}102 \\
(95-165)\end{array}$ & 0,546 \\
\hline $\begin{array}{l}\text { Jumlah cairan } \\
\text { intraoperatif (mL) }\end{array}$ & & $\begin{array}{c}1.954,9 \\
(413,27)\end{array}$ & $\begin{array}{c}1.760 \\
(1.581-2.835)\end{array}$ & & $\begin{array}{c}2076 \\
(508,29)\end{array}$ & $\begin{array}{c}1.756 \\
(1.579-2.831)\end{array}$ & 0,756 \\
\hline
\end{tabular}

Keterangan: Nilai p untuk usia, BMI, lama operasi dan jumlah cairan intraoperatif dihitung berdasarkan uji t tidak berpasangan dan Mann-Whitney (ZM-W), bermakna bila $\mathrm{p}<0,05$. Nilai $\mathrm{p}$ untuk pendidikan dan interval usia dihitung berdasarkan uji chi-kuadrat, bermakna bila $\mathrm{p}<0,05$

Peningkatan jumlah magnesium di dalam darah pascaoperasi pada kelompok M sebesar $19,8 \%$ bila dibandingkan dengan praoperasi, dan penurunan jumlah magnesium di dalam darah pascaoperasi pada kelompok S sebesar $15,9 \%$ dibandingkan dengan praoperasi (Tabel 3). Berdasarkan uji statistik menggunakan uji-t didapat hasil perbandingan kadar magnesium darah praoperasi kedua kelompok perlakuan secara statistik yang tidak berbeda bermakna ( $p>0,05)$.

\section{Pembahasan}

Prevalensi terjadi nyeri akut dan kronik akan meningkat sejalan dengan peningkatan usia pasien disebabkan karena penurunan sistem kontrol nyeri endogen serta terjadi degenerasi sistem muskuloskeletal yang bersifat progresif.
Peningkatan usia juga memberikan pengaruh terhadap penurunan mekanisme inhibisi nyeri yang disebabkan oleh rangsang noksius yang bersifat difus terutama usia di atas 50 tahun. ${ }^{17}$

Operasi abdominal ginekologi merupakan jenis operasi yang mengakibatkan intensitas nyeri pascaoperasi cukup tinggi, sehingga jenis operasi ini akan membutuhkan penanganan nyeri pascaoperasi yang lebih baik. ${ }^{4}$ Kualitas nyeri pascabedah dinilai dengan menggunakan skor VAS saat mobilisasi pasien. Nilai VAS saat mobilisasi pada kelompok M menunjukkan nilai yang lebih rendah dan bermakna secara statistik bila dibandingkan dengan kelompok S sampai pengukuran jam ke-6 pascabedah ( $p<0,05$; Tabel 2).

Magnesium bekerja sebagai penghambat saluran kalsium dan juga antagonis terhadap reseptor NMDA sehingga dapat memberikan 


\begin{tabular}{lccc}
$\begin{array}{c}\text { Tabel } 2 \\
\text { Perbandingan Nilai VAS Pascabedah } \\
\text { Saat Mobilisasi pada Kedua } \\
\text { Kelompok Perlakuan }\end{array}$ \\
\hline $\begin{array}{c}\text { Nilai } \\
\text { VAS }\end{array}$ & $\begin{array}{c}\text { Kelompok } \\
\text { M } \\
(\mathbf{n = 1 5})\end{array}$ & $\begin{array}{c}\text { Kelompok } \\
\text { (n=15) }\end{array}$ & Nilai p \\
\hline T0 & $0-1$ & $0-1$ & 0,001 \\
$\mathrm{~T} 1$ & $1-2$ & $1-2$ & 0,002 \\
$\mathrm{~T} 2$ & $1-2$ & $1-4$ & 0,000 \\
$\mathrm{~T} 4$ & $1-2$ & $1-4$ & 0,028 \\
$\mathrm{~T} 6$ & $2-5$ & $2-5$ & 0,016 \\
$\mathrm{~T} 12$ & $2-5$ & $3-5$ & 0,284 \\
$\mathrm{~T} 18$ & $2-5$ & $4-5$ & 0,239 \\
$\mathrm{~T} 24$ & $2-4$ & $2-5$ & 0,274 \\
\hline
\end{tabular}

Keterangan: $\mathrm{T} 0=30$ menit, $\mathrm{T} 1=1 \mathrm{jam}, \mathrm{T} 2=2$ jam, dan seterusnya. Nilai p untuk VAS pascabedah pada saat mobilisasi dihitung berdasarkan uji chi-kuadrat, bermakna bila $\mathrm{p}<0,05$
Pelepasan neurotransmiter serta substansi lain pada proses nyeri dan inflamasi jaringan akan terhambat karena blok saluran kalsium oleh magnesium. Efek antinosiseptif lainnya adalah perubahan pada tingkat eksitasi pada kolumna dorsalis medula spinalis sehingga memengaruhi persepsi terhadap nyeri. ${ }^{19}$

Tujuan pemberian analgetik pertolongan petidin ialah menghilangkan nyeri pascabedah yang tidak tertangani oleh analgetik rumatan. Dosis petidin yang diberikan adalah $0,5 \mathrm{mg} /$ $\mathrm{kgBB}$ bolus intravena setiap kali pemberian dan akan diulang sampai subjek penelitian ini merasa nyaman.

Jumlah obat analgetik pertolongan petidin yang dibutuhkan kelompok M selama 24 jam pascaoperasi lebih sedikit bila dibandingkan dengan kebutuhan pada kelompok $S(p<0,05)$. Penurunan intensitas nyeri serta kebutuhan

Tabel 3 Jumlah Analgetik Petidin yang Dibutuhkan dalam 24 Jam Pascabedah

\begin{tabular}{|c|c|c|c|c|c|}
\hline Jumlah Peditin (mg) & \multicolumn{2}{|c|}{ Kelompok M $(n=15)$} & \multicolumn{2}{|c|}{ Kelompok $S(n=15)$} & $\frac{\text { Nilai p }}{0,011}$ \\
\hline Rata-rata (SD) & 48,09 & $(23,15)$ & 51,04 & $(23,11)$ & \\
\hline Median (Rentang) & 47,00 & $(23-114)$ & 50,00 & $(23-110)$ & \\
\hline
\end{tabular}

Keterangan: nilai p dihitung berdasarkan Uji Mann-Whitney (ZM-W), bermakna bila $p<0,05$

efek analgetik. Dengan menghambat reseptor $N$-methyl-D-aspartate (NMDA) maka proses sensitisasi saraf pusat akibat stimulasi perifer akan terhambat serta menghilangkan reaksi hipersensitivitas. Sensitisasi saraf yang terjadi biasanya berupa penurunan ambang rangsang nyeri pascatrauma dan juga hipersensitivitas refleks di sekitar daerah yang cedera. ${ }^{12,14,18}$ analgetik pascaoperasi pada kelompok pasien yang mendapatkan magnesium kemungkinan disebabkan terjadi keadaan hipomagnesemia dapat dihindari sehingga mencegah aktivasi reseptor NMDA. ${ }^{20}$

Kadar magnesium serum saat pascabedah pada kelompok S berkurang rata-rata 15,9\%, sedangkan kelompok $\mathrm{M}$ meningkat rata-rata

Tabel 4 Kadar Magnesium Darah

\begin{tabular}{lccc}
\hline Kadar Magnesium & Kelompok M (n=15) & Kelompok S (n=15) & p \\
\hline Praoperasi (mg/dL) & $1,97+0,20$ & $1,95+0,10$ & 0,779 \\
Pascaoperasi (mg/dL) & $2,36+0,32$ & $1,64+0,16$ & 0,000 \\
Perubahan kadar & $+19,8 \%$ & $-15,9 \%$ & \\
Magnesium (\%) & & & \\
\hline
\end{tabular}

Keterangan: Nilai p untuk kadar magnesium darah dihitung berdasarkan uji t tidak berpasangan, bermakna bila $\mathrm{p}<0,05$ 
19,8\% apabila dibandingkan dengan prabedah (Tabel 4). Tidak terdapat korelasi antara dosis kumulatif magnesium yang diberikan dan peningkatan kadar magnesium darah. ${ }^{20}$

Mekanisme hipomagnesemia pascaoperasi belum diketahui secara pasti, hal ini diduga berhubungan sekali dengan penurunan kadar albumin dalam darah sehingga ikatan protein dan magnesium juga menurun. Kadar protein serta albumin yang menurun secara signifikan berhubungan erat dengan jumlah cairan yang diberikan. Angka kejadian hipomagnesemia ini meningkat dari 19,2\% pada saat praoperasi menjadi $71 \%$ segera pascaoperasi, serta akan menurun menjadi sebesar $65,6 \%$ setelah 24 jam kemudian. Penurunan kadar magnesium dalam darah di bawah ambang batas fisiologis dapat meningkatkan responsivitas reseptor $N$-methyl-D-aspartate (NMDA). ${ }^{12,19,20}$

\section{Simpulan}

Penelitian ini memberikan simpulan bahwa pemberian bolus magnesium sulfat intravena dosis $30 \mathrm{mg} / \mathrm{kgBB}$ selama 15 menit sebelum induksi dan dilanjutkan dengan dosis rumatan $10 \mathrm{mg} / \mathrm{kgBB} / \mathrm{jam}$ sampai akhir operasi mampu memberikan nilai VAS pascaoperasi yang lebih rendah serta mengurangi dosis total analgetik pertolongan petidin pascaoperasi.

\section{Daftar Pustaka}

1. Kirwan T. Post-operative pain. Dalam: Holdcroft A, Jaggar S, penyunting. Core topics in pain. New York: Cambridge University Press; 2005. hlm. 161-70.

2. Lubenow TR, Ivankovich AD, Barkin RL. Management of acute post operatif pain. Dalam: Barash PG, Cullen BF, Stoelting RK, penyunting. Clinical anesthesia. Edisi ke-5. Philadelphia: Lippincot William \& Wilkins; 2006. hlm. 1405-34.

3. Rao M. Acute postoperative pain. Indian J Anaesth. 2006;50(5):340-4.

4. Dolin SJ, Cashman JN, Bland JM. Effectiveness of acute postoperative pain management. Evidence from published data. Br J Anaesth. 2002;89(3):409-23.

5. Kehlet $\mathrm{H}$, Holte $\mathrm{K}$. Effect of postoperative analgesia on surgical outcome. $\mathrm{Br} \mathrm{J}$ Anaesth. 2001;87:67-72.

6. Breivik $H$. The future role of the anaesthesiologist in pain management. Acta Anaesthesiol Scandinavica. 2005;49: 922-6.

7. Atiyat B, Kloub A, Abu-halaweh S. Comparison of three modes of pain relief after major surgery. Eur J Scientific Research. 2009;32(2):194-200.

8. Sarantopoulus C. A practical approach to postoperative pain management. Dalam: Abram SE, penyunting. Edisi ke-1. Pain medicine: the requisites in anesthesiology. Philadelphia: Mosby Elsevier's; 2006. hlm. 98-113.

9. Marsaban AHM, Bagianto H, Ma'as EM. Ilmu pengetahuan dasar. Dalam: Chandra $S$, penyunting. Panduan tatalaksana nyeri perioperatif. Jakarta: PP IDSAI; 2009. hlm. $1-23$.

10. Habib AS, Gan TJ. Role of analgesic adjuncts in postoperative pain management. Anesthesiology. 2005;23:85-107.

11. Levaux $\mathrm{CH}$, Bonhomme $\mathrm{V}$, Dewandre PY. Effect of intra-operative magnesium sulphate on pain relief and patient comfort after major lumbar orthopaedic surgery. Anaesthesia. 2003;58:131-5.

12. Dube L, Granry JC. The therapeutic use of magnesium in anesthesiology, intensive care and emergency medicine: a review. Can J Anesth. 2003;50(7):732-46.

13. Tanra AH. Nyeri pascabedah dan pengelolaannya. Anestesia \& Crit Care. 2005;23:152-8.

14. Širvinskas E, Laurinaitis R. Use of magnesium sulfate in anesthesiology. Medicina. 2002;38(7):695-8.

15. Barbosa FT, Barbosa LT, Jucá MJ, da Cunha RM. Applications of magnesium sulfate in obstetrics and anesthesia. Rev Bras Anestesiol. 2010;60(1):481-97.

16. White PF. Non-opioid analgesics for acute perioperative pain past, present, and future. Anesthesiology. 2007;1:1-7.

17. White PF. The changing role of nonopioid 
118 | Jurnal Anestesi Perioperatif

analgesics techniques in the management of postoperative pain. Anesth Analg. 2005;101:s5-22.

18. Tracey I. Imaging pain. $\mathrm{Br} J$ Anaesth. 2008;101:32-9.

19. Morgan JE, Mikhail MS, Murray MJ. Pain management. Dalam: Kelen GD, penyunting. Clinical anesthesiology. Edisi ke-4. New York: McGraw Hill Companies; 2006. hlm. 359-411.

20. Lysakowsky C, Dumont L, Czarnetzki C, Tramer MR. Magnesium as an adjuvant to postoperative analgesia: a systematic review of randomized trials. Anesth Analg. 2007;104(6):1532-9. 